\title{
The Relationship between Fourth-Grade Primary School Students' Story-writing Skills and Their Motivation to Write
}

\author{
Hayati Akyol, Nurhan Aktaş* \\ Department of Elementary Education, Faculty of Education, Gazi University, Turkey
}

Copyright $(2018$ by authors, all rights reserved. Authors agree that this article remains permanently open access under the terms of the Creative Commons Attribution License 4.0 International License

\begin{abstract}
The aim of this study is to examine the relationship between fourth-grade primary school students' story-writing skills and their motivation to write. The study group of the research is made up of 165 fourth-grade students. The study was conducted within the framework of the survey model. Within the scope of the research, the Motivation to Write Profile, an assessment tool developed by Codling and Gambrell [7], was used to measure the students' motivation to write, while the 6+1 Analytic Writing and Evaluation Scale adapted to Turkish by Özkara [26] was used for assessing the students' story-writing skills. In the study, it was determined that female students' writing motivation scores were higher than those of male students and that, moreover, female students' story-writing skills were more developed than those of male students. Furthermore, it was seen that the students' story-writing skills had a significant positive relationship with the value they placed on writing and with their self-efficacy as writers.
\end{abstract}

Keywords Story-writing Skills, Motivation to Write, Primary School Students

\section{Introduction}

A story is a narration that deals with events that have happened or might happen within the context of events, place, time and people, with the aim of making reference to a certain idea. Stories are effective reading texts that offer the reader the opportunity to speculate, explain the meaning, organise, recall and solve problems [2] Although story comprehension begins in children in the preschool years, it is known that around the age of eight, children reach a level where they can remember all the elements of a story. However, the story is a type of writing about which children begin to be curious after a certain age. At the ages of $10-12$, children begin to take an increasing interest in this type of writing [34]. This period can be called the age at which children take an interest in real life. Children develop their story comprehension over a period of time in stages, namely by listening to what is narrated to them, by explaining what they have read, and by writing $[2,35]$. Furthermore, the story occupies an important place in children's interpretation of what they have read [35].

Since the story contains a single event, it appears to be an easy type of writing to write. Once students have acquired the skill of writing, it is the first type of writing to be taught to them. The writing skill is one of the language skills that are taught to students in the first years of elementary school. Various processes, skills, techniques, operations and dimensions found in other areas are included in this learning domain [13]. Motivation is also one of these dimensions and this has an important place in language learning.

Motivation may differ from person to person. People not only have different levels of motivation, they also have different motivations. That is, not only the level of motivation, but also its source is varied [31].This situation also applies to writing motivation. Lo and Hyland [19], who consider writing as a need, deal with motivation, which is a process leading students towards their goals, as a factor which directs students' learning activities and interests. For example, while one student may do better and more successful writing homework with the aim of being appreciated by his or her family, teacher or environment, another student may do this purely for himself or herself or because he or she derives pleasure from it. Chakraborty and Stone [6] stated that the motivation to write begins when opportunities needed for creativity overlap with students' interests.

Motivation plays an important role in the development of students' writing skills. In order to minimise individual differences that may appear in the development of this skill, the teacher must also include activities aimed at increasing 
writing motivation in the teaching process. Provided that the necessary education is given, it is possible to increase motivation in teaching [42]. Students who are well motivated in the learning environment use their learning capacities in the best way and perceive themselves as more successful with regard to writing [33]. To increase the motivation to write, it can be recommended that students be encouraged to write about subjects that interest them, that they be allowed to make a choice as to what they are to write, and that they be given the chance to control what is written [5].

Two factors come to the fore in writing motivation. These are "writer self-efficacy" and "writing task value". According to Shavelson, self-efficacy is formed by a person's individual perception of their behaviours resulting from their interactions with their environment, while according to Burns, self-efficacy is the total of all a person's beliefs and values regarding himself or herself [27]. According to another definition, however, self-efficacy is an individual's view of himself or herself and is formed by his or her attitudes, emotions, perceptions and behaviours [12].

Self-efficacy is based upon an individual's learning beliefs regarding his or her capacity, skills and endeavour. Competence belief is an individual's self-evaluation as to whether or not he or she possesses the necessary skills for performing a task [7]. Self-efficacy is an important factor in learning [3,9]. Individuals who regard themselves as qualified are more motivated to take part in an activity.

Another factor related to writing motivation is task value. Writing task value is a concept in which information is obtained regarding how much writers include writing in their daily lives and how often they make efforts to write. For an individual to determine whether he or she has made the necessary effort to accomplish a task or not, how much that person values that task is important. Value placed on a task is related to how much importance a student attaches to that task and to how interested he or she is in that task.

It is seen that a scale with a similar structure to that of the writing motivation scale is found in the field of reading motivation. In the Reading Motivation Profile questionnaire, adapted to Turkish by Yildiz [39], the concepts of reading task value and reader self-efficacy are referred to. Reading task value is a concept including information on how many readers include reading in their daily lives and how often they engage in reading. Reader self-efficacy is explained as a concept related to how much an individual considers himself or herself competent in reading skills.

It is also seen that one of the factors affecting writing motivation is gender. Examining the studies conducted $[21,22,28]$, it was determined that female students were more motivated to write and had higher levels of writer self-efficacy compared to male students, and that they wrote with a specific aim in mind.

In a study by Takımcigil Özcan [33], the effect of writing motivation on the story-writing skills of fourth-grade primary school students was examined. When the story-writing skills of the students participating in the study were examined according to the gender variable, it was found that the mean scores in story-writing skills of female students were significantly higher than those of male students. Moreover, when the writing skills of students from different socioeconomic levels were examined with regard to gender, it was determined that the mean scores in writing skills of female students from each socioeconomic level (lower, middle and upper) were higher than those of male students. It was concluded in the study that gender and socioeconomic level had a significant effect on the fourth-grade students' motivation to write. According to the study, scores for writing motivation in female students were higher than those of male students. Furthermore, it was determined that there was a significant relationship between motivation to write and story-writing ability.

In a study by Lam and Law [17], the relationship between students' writing motivation and their writing performance was researched. The study group of the research was made up of six teachers and their students in Hong Kong. During the study, the teachers taught expository-type text-writing. After the students had completed their writing tasks, a questionnaire was applied in order to learn their opinions about their motivation to write and the writing process. The study revealed that there was a significant relationship between the students' motivation to write and their writing performance. In other words, it was seen that as writing motivation increased, there was also an improvement in writing performance. Moreover, it was found that when the teachers used more motivating writing strategies, the students were also more motivated to write.

In a study conducted by Troia, Harbaugh, Shankland, Wolbers and Lawrence [37], students' story-writing skills were examined with regard to certain variables. The study group of the research was made up of 618 primary school students from 4th grade up to 10th grade (except for 8 th grade). In the study, it was determined that students with good writing ability, female students and students in higher grades were better at writing fictional stories. Moreover, it was determined that students in lower grades, female students and students with better writing skills compared to their peers allocated more time to writing activities both in and out of school. Furthermore, it was concluded that the grade level and gender variables had a direct effect on the students' writing activities. It was determined that as grade level increased, the students became better at writing fiction, and that story-writing skills in female students were more developed than those of male students.

In a study by Yıldız, Aktaş, Yekeler and Ataş [40], in which primary and middle school students' story-writing skills were examined with regard to grade level, it was concluded that at almost all grade levels, female students 
included more story components in their stories than male students did, and when story quality was considered, it was found that total scores obtained for story quality were higher as grade level increased and that female students were also ahead of male students regarding the quality of their stories.

In the current study, motivation for writing has been examined by considering the writing task value and writer self-efficacy dimensions. As the opportunities brought by the age of technology increase in our era, an attempt has been made to ascertain the effect of changes in the value students place on writing and writer self-efficacy on their story-writing skills. This study is important in that it is the first study in Turkey that deals with the relationship between writing motivation and the concepts of "writer self-efficacy" and "writing task value". From this aspect, it differs from writing motivation studies appearing in the literature. The aim of this study is to examine the relationship between fourth-grade primary school students' story-writing skills and their motivation to write. In line with this aim, answers were sought to the following questions:

1. Does the writing motivation of fourth-grade primary school students show a significant difference according to their gender?

2. Do the story-writing skills of fourth-grade primary school students show a significant difference according to their gender?

3. Is there a significant relationship between writing motivation and story-writing skills in fourth-grade primary school students?

4. To what extent does writing motivation in fourth-grade primary school students predict their story-writing skills?

\section{Method}

\subsection{Research Design}

In this study, in which the relationship between motivation to write and story-writing skills in fourth-grade primary school students was examined, the scanning model was used. The scanning model is defined as a research design approach that aims to describe a past or existing situation as it is [16]. In the study, this model was selected because it attempts to determine the degree of the relationship between the variables (story writing and motivation to write) by describing an existing situation. What is important in the scanning model is that an existing situation can be observed without changing it.

\subsection{Study Group}

In the study, data was gathered from 200 fourth-grade students studying at two state schools located in the
Çankaya district of Ankara during the 2017-2018 academic year. However, following the cleaning of the data, 35 students were removed from the data set. The statistical analyses were carried out on the data obtained from 165 fourth-grade students. Examining the distribution of the students participating in the study according to gender, it is seen that about $54 \%$ of the students were girls $(\mathrm{N}=89)$, while about $46 \%$ of them were boys $(\mathrm{N}=76)$. The schools in which the study was conducted are state schools with a medium socioeconomic level. It can be said that the schools have similar levels of academic success to each other. The convenience sampling method was used to select the study group. This sampling technique includes voluntary participants who are suitable for the research aim [8].

\subsection{Data Collection Tools}

As the data collection tools for the research, the Motivation to Write Profile developed by Codling and Gambrell [7] and the 6+1 Analytic Writing and Evaluation Scale developed by Özkara [26] were used.

Motivation to Write Profile Scale: This scale, developed by Codling and Gambrell [7] was designed for assessing motivation to write in students from second grade up to sixth grade. It consists of two parts. The first part was designed under the heading of "scale for determining writing task value and writing self-concept", while the second part consists of face-to-face interviews. This questionnaire can be conducted with the whole class at the same time in order to determine the writing motivation of the whole class. The scale in made up of a 14-item "writing task value" dimension and a 12-item "writing self-concept" dimension. The writing task value dimension is divided into three sub-groups, namely narrative writing (3 questions), expository writing (3 questions) and general writing (8 questions). The writing self-concept dimension is similarly divided into three sub-groups, namely narrative writing (4 questions), expository writing (4 questions) and general writing (4 questions). The scale items are arranged as four-response Likert-type questions. The options for items with positively-oriented questions are scored from positive to negative as "4-3-2-1", while items having negatively-oriented questions are scored in the opposite direction for calculating total scores.

\section{Adaptation of Motivation to Write Profile Scale to Turkish:}

Work on adaptation of the scale to Turkish was begun in May 2017.

\section{Linguistic Equivalence}

The original version of the scale was translated into Turkish by two linguists. The Turkish version of the scale was presented to four academicians and lecturers working in the field of writing education in order to obtain their views. The experts evaluated the scale to determine 
whether or not the items conformed to the original ones and whether or not the words or concepts included in the items were the same in both cultures. Following the assessments, revisions were made related to certain errors in translation and to cultural confusion. After the scale had been revised, the new version was again sent to the linguists. It was seen that there was consistency between the original and translated versions of the scale.

\section{Validity}

230 students attending fourth grade of primary school took part in the adaptation. The validity and reliability studies were conducted in line with the students' answers. To determine the construct validity of the Motivation to Write Scale, confirmatory factor analysis (CFA) was performed. A number of the items in the scale have negative meanings. While CFA was being performed, these items were coded reversely and total scores were calculated by distributing scoring in the opposite way to normal distribution. Confirmatory factor analysis was carried out with the AMOS (Analysis of Moment Structures) software. AMOS is a statistical programme used in structural equation modelling [24]. For CFA, goodness of fit index values are involved. It is stated that GFI, RFI, CFI and IFI indices at values greater than .90 determine that these values show sufficient fit, that SRMR at values approaching 1 shows perfect fit, and that RMSEA at values less than .05 have a good fit value [32]. These values were taken into consideration during the data analysis. The statistical analyses were performed using the SPSS 17 and AMOS 18 programmes. The CFA results of the scale are as follows:

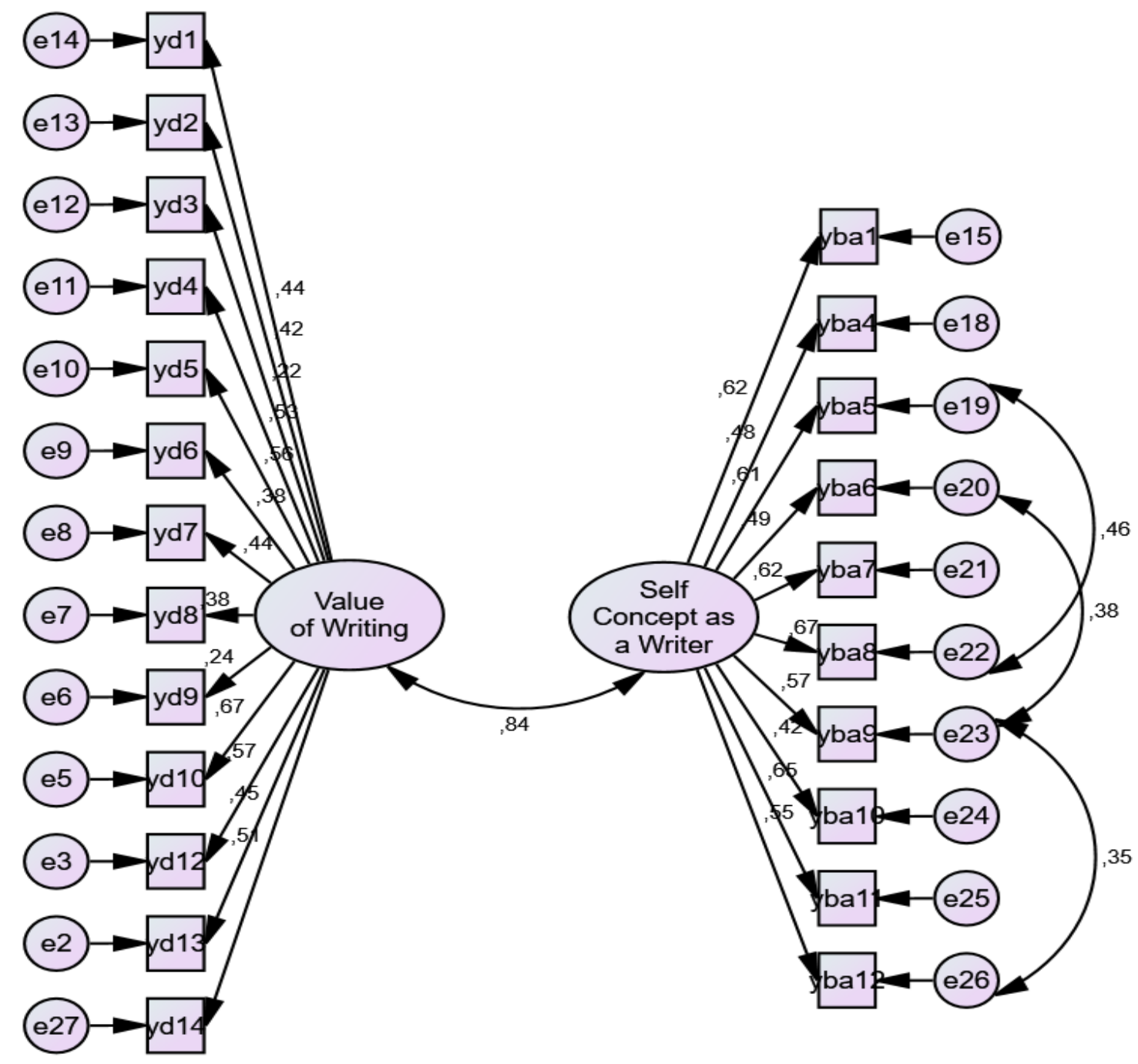

Figure.1. CFA Results of Motivation to Write Scale 
It was determined that the correlation coefficient calculated for the observed variables (items) of the factors (writing task value, writer self-efficacy) ranged between .23 and .75 and that this was significant. $\mathrm{RMSEA}=.07, \mathrm{RMR}=.05, \mathrm{GFI}=.83$ and $\mathrm{CFI}=.81$ were found. Considering the values obtained following the CFA, it is observed that the fit values of the model are at acceptable levels. Due to multicollinearity problems, item 11 of the Writing Task Value factor and items 2 and 3 of the Writer Self-Efficacy factor were removed from the scale.

\section{Reliability}

Considering the reliability values, the values of $a=.81$ for the 13-item Value factor, $a=.83$ for the Self-Efficacy factor and $a=.89$ for the total scale show that it has a high degree of reliability.

$6+1$ Analytic Writing and Evaluation Scale: The scale developed as the $6+1$ Analytic Writing and Evaluation Model by Education Northwest (2006) was adapted to Turkish by Özkara [26]. In the scale, the characteristics necessary for a good-quality piece of writing are given under 7 headings. The headings included in the scale are ideas, organisation, wording, word choice, sentence fluency, spelling and presentation. Pieces of writing produced by students were evaluated and scored as 5,3 and 1 by two researchers by considering the criteria for the characteristics found in the $6+1$ Analytic Writing and Evaluation Scale. According to the scale, the maximum score that can be attained from a story is 35 .

\subsection{Data Collection}

The data for the writing motivation scale were gathered from state schools with similar socioeconomic levels located in the Çankaya district of Ankara. The data collection process lasted three weeks. First, the principals and class teachers at the schools where the research was to be carried out were met, information about the study was given and consent was obtained. Then, information about the implementation to be made was given to the students, and the implementation was carried out with students willing to participate in the study. The data were gathered by the researcher in every class. After the implementation guidelines for the scale had been read to the students, examples given by the researcher were written on the board and example markings were made. In this way, the students were informed about the marking technique for the scale. Next, the researcher read out each item in the scale, after which the students individually answered the items included in the scale. For each class, answering the scale items took about 30 minutes. Finally, the story writing topics printed on the back part of the scale were read to the students, who were then asked to write a story about one of the topics within a period of 30 minutes.

\subsection{Data Analysis}

Data for the research were gathered from a total of 200 students. The data took their final form with 165 students following initial examination by performing extreme value analysis. While the stories were being scored, the researchers performed separate scoring independently of each other and the obtained data were compared. Following the comparisons related to the scoring, the researchers reconsidered situations in which they disagreed and scrutinised the analyses until they had reached an agreement on contradictory situations.

For analysis of the data gathered during the research, the SPSS 16.0 statistical software package was used. The content of the stories was analysed according to the $6+1$ Analytic Writing and Evaluation Scale, by considering whether the students had written titles for their stories, and according to the number of paragraphs and the number of words used in the stories. Frequency (f) and percentage (\%) distribution were calculated in the analysis of these data.

The content of the stories was analysed according to certain qualities (ideas, organisation, wording, word choice, sentence fluency and presentation) included in the $6+1$ Analytic Writing and Evaluation Scale. Each quality was scored as 5-3-1 according to whether it was included in the story. The normal distribution variances of the data were examined, and since normal distribution was observed, the scores related to the story qualities and the numbers of words in the stories were calculated with t-test for independent samples according to gender. In the performed analyses, $\mathrm{p}<.05$ was taken as significant.

\section{Findings}

In this section, the findings obtained from the analysis of the study data are presented.

\subsection{Findings Related to the First Research Question}

Findings related to the question, "Does the writing motivation of fourth-grade primary school students show a significant difference according to their gender?" are presented in Table 1.

Table 1. T-test Results of Students' Writing Motivation Scores According to Gender

\begin{tabular}{ccccccc}
\hline Factors & Gender & $\mathbf{N}$ & $\mathbf{X}$ & $\mathbf{s d}$ & $\mathbf{T}$ & $\mathbf{P}$ \\
\hline $\begin{array}{c}\text { Writing } \\
\begin{array}{c}\text { Self } \\
\text { Efficacy }\end{array}\end{array}$ & Female & 89 & 31.8 & 4.44 & 5.11 & \\
\cline { 2 - 6 } & Male & 76 & 27.7 & 5.73 & 5.01 & $.00^{*}$ \\
\hline \multirow{2}{*}{$\begin{array}{c}\text { Value of } \\
\text { Writing }\end{array}$} & Memale & 89 & 39.9 & 4.87 & 2.77 & \\
\cline { 2 - 6 } & Male & 76 & 37.6 & 5.94 & 2.72 & $.00^{*}$ \\
\cline { 2 - 6 } TOTAL & Memale & 89 & 71.7 & 8.38 & 4.25 & \multirow{2}{*}{$.00^{*}$} \\
\cline { 2 - 5 }$* \mathrm{P}<.05$ & & 76 & 65.3 & 10.9 & 4.16 & \\
\hline
\end{tabular}

Examining Table 1, it can be seen that there is a significant difference $(p<.05)$ in favour of female students for both dimensions of motivation (writing task value and writer self-efficacy). It can be said that motivation to write 
is higher in female students than in male students.

\subsection{Findings Related to the Second Research Question}

Findings related to the question, "Do the story-writing skills of fourth-grade primary school students show a significant difference according to their gender?" are presented in Table 2 .

Table 2. T-test Results of Students' Story-Writing Skills according to Gender

\begin{tabular}{|c|c|c|c|c|c|c|}
\hline & Gender & $\mathbf{N}$ & $\mathbf{X}$ & sd & $\mathbf{t}$ & $\mathbf{P}$ \\
\hline \multirow{2}{*}{ Story-Writing } & Female & 89 & 21.3 & 4.0 & 4.78 & $.00 *$ \\
\hline & Male & 76 & 17.9 & 4.9 & 4.70 & \\
\hline
\end{tabular}

Examination of Table 2 reveals that there is a significant difference in favour of female students with regard to scores obtained by students from the " $6+1$ Analytic Writing and Evaluation Scale". It is seen that female students obtained higher scores compared to male students. According to this finding, it may be stated that female students write better-quality stories than male students do.

\subsection{Findings Related to the Third Research Question}

Findings related to the question, "Is there a significant relationship between writing motivation and story-writing skills in fourth-grade primary school students?" are presented in Table 3.

Table 3. Correlation Results for Relationship between Students' Story-Writing Skills and their Writing Motivation

\begin{tabular}{cccc}
\hline & Story & Self & Value \\
\hline Story & 1 & $45^{* *}$ & $41^{* *}$ \\
\hline Writing Self Efficacy & & 1 & $71^{* *}$ \\
\hline Value of Writing & & & 1 \\
\hline $\mathrm{P}<.01^{* *}$ & & &
\end{tabular}

Examining Table 3, it is seen that there is a significant positive relationship between students' story-writing skills and the value they place on writing (.41) as well as their writer self-efficacy (.45). These findings reveal that as the value placed on writing by students and their perception of themselves as competent writers increase, their story-writing scores also increase.

\subsection{Findings Related to the Fourth Research Question}

Findings related to the question, "To what extent does writing motivation in fourth-grade primary school students predict their story-writing skills?" are presented in Table 4.

Table 4. Regression Results for Predicting Students' Story-Writing Skills

\begin{tabular}{ccccc}
\hline Predictors & $\mathrm{B}$ & $\mathrm{SE} \mathrm{B}$ & $\beta$ & $\mathrm{R}^{2}$ \\
\hline Writing Self Efficacy & 29 & 09 & $34^{* *}$ & \multirow{2}{*}{.23} \\
\cline { 1 - 4 } Value of Writing & 15 & 08 & 17 & \\
\hline
\end{tabular}

Examination of Table 4 reveals that there is a significant effect of writer self-efficacy on the quality of writing $(\beta=.34, p<.001)$, whereas the effect of value placed on writing is not significant $(\beta=.17, \mathrm{p}>.001)$. Moreover, writer self-efficacy and value placed on writing account for $23 \%$ of story-writing ability.

\section{Discussion and Conclusions}

In this study, in which the relationship between students' story-writing skills and their motivation to write was examined, the findings obtained from the research are as follows:

It was determined that writing motivation in female students was higher than in male students. It is known that motivation to write is a factor, which creates the will and strength that directs an individual towards the act of writing and which enables the continuation of that act of writing. In this study, motivation to write consists of two factors, namely writing task value and writer self-efficacy. Writing task value is a concept in which information is obtained regarding how much writers include writing in their daily lives and how often they make efforts to write. It was seen in the study that the value placed on writing by female students was higher. In forming the gender classification related to motivation, family, school and sociocultural factors are involved [10]. Parents' perceptions of their children's abilities have an effect on their children's own perceptions of their abilities [15]. School plays a key role in forming children's beliefs related to gender roles and their social identities [30]. Teachers' expectations regarding gender change according to grade level, the student's ability, the subject area and the school environment [43]. It is known that activities aimed at developing literacy skills that begin to develop in the teaching-learning process particularly at primary school level are more suited to meeting the expectations of girls [4]. According to Malecki and Jewell [20], female students' attitudes towards writing are more positive in comparison with those of male students. It is stated that possession of this positive attitude has a positive impact on students' motivation and that it leads to positive changes in writing skills.

Writer self-efficacy is based upon an individual's beliefs regarding his or her writing ability and writing capacity. It is related to how an individual regards himself or herself as a writer. Writer self-efficacy has an impact on students' writing skills. In Large et al's [18] study, it was observed that $49 \%$ of the 137 participants in the survey gave a positive response to the item "Do you consider yourself an author?" while $50 \%$ gave a negative response and $1 \%$ stated that they were not sure. It was seen that the students who considered themselves authors, that is, those who regarded themselves as competent to write, stated that they liked writing and that their parents could also write well. 
However, it was determined that those who did not consider themselves authors, that is, those who did not feel competent in writing, merely stated that they did not like writing.

The current study revealed that there were significant differences in writing motivation scores between male and female students. In terms of gender, this difference revealed in the results of the study shows similarity with results of studies conducted both in Turkey and abroad. It can be said that the findings obtained in this study are consistent with the findings of research by $[1,11,23,25,29,33,36,37,40,41]$. In the aforementioned studies, it is reported that female students are ahead of male students with regard to writing motivation scores.

Another finding of the study is that there was a significant difference in terms of gender in the quality of the stories written by the students. Scores of female students were higher than those of male students. This situation shows that female students were ahead of their male counterparts with regard to giving the main idea of the story (main idea), completion of the introduction, development and conclusion in coherence (organisation), care with language used in the writing (wording), correct and meaningful use of words (word choice), integration of the writing and use of fluent statements (sentence fluency) and conforming with the rules of grammar and writing with readable handwriting (presentation, spelling). Examining the literature, findings of studies revealing that female students are ahead of male students with regard to writing skills show similarity with the findings of the present study $[33,40]$.

Another finding obtained in the research is that as students' motivation for writing increased, their story-writing scores also increased. It was seen that as the value placed on writing by students and their perception of themselves as competent in writing increased, their story-writing scores also increased. In a study carried out by Hidi and Boscolo [14], it is reported that students who were self-confident while writing and who had motivation to write, were satisfied with their writing performance and more willing to take part in new writing tasks. Whereas students with weak writing ability were likely to have low levels of motivation, feel anxiety towards writing and have low levels of writing skills. It is seen that the findings of that study, which deals with the importance of motivation level for writing ability, are consistent with the findings of the present study.

\section{REFERENCES}

[1] Acat, M.B. ve Yenilmez, K. (2004). Eğitim Fakültesi Öğrencilerinin Öğretmenlik Mesleğine İlişkin Motivasyon Düzeyleri ve Sorunları, XII. Eğitim Bilimleri Kongresi Bildirileri, Gazi Üniversitesi Eğitim Bilimleri Enstitüsü, (Cilt-I) Ankara.
[2] Akyol, H. (2014). Programa uygun Türkçe öğretim yöntemleri. Ankara: Pegem A.

[3] Bandura, A. (1989). Human agency in social cognitive theory. American Psychologist, 44, 1175-1184.

[4] Brozo, W. G. (2002). To Be a Boy, To Be a Reader: Engaging Teen and Preteen Boys in Active Literacy. Newark, DE: International Reading Association.

[5] Bruning, G. \& Horn, C. (2000). Developing motivation to write. Educational Psychologist. 35 (1), 25-37.

[6] Chakraborty, B. \& Stone, S. (2008). A recipe for writing motivation. Childhood Education, 84 (3), 158-G(4). Expanded Academic ASAP. Online Makale. http://www.highbeam.com/doc/1G1

[7] Codling, R. M \& Gambrell, L. B. (1997). The motivation to write profile: an assessment tool for elementary teachers. National Reading Research Center, Universities of Georgia and Maryland Instructional Resource, 38.

[8] Creswell, J. W. (2005). Educational research: Planning, conducting, and evaluating quantitative and qualitative research. New Jersey: Pearson Education, Inc

[9] Deci, E. L, Vallerand, R, J., Pelletier, L. G., \& Ryan, R. M. (1991). Motivation and education: The self-determination perspective. Educational Psychologist, 26, 325-346.

[10] Eccles, J. S., Adler, T. F., Futterman, R., Goff, S. B., Kaczala, C. M., \& Meece, J. L. (1983). Expectancies, values, and academic behaviors. In J. T. Spence (Ed.), Achievement and achievement motivation (pp. 75-146). San Francisco, CA: W. H. Freeman.

[11] Erten, H. (2006). Ortaöğretim Öğrencilerinin Kimya Derslerine Yönelik Güdülenme Tür (içsel ve Dişsal) ve Düzeylerinin Bazı Değişkenler Açısından İncelenmesi. Balıkesir Üniversitesi Fen Bilimleri Enstitüsü. Yüksek Lisans Tezi.

[12] Gander, M. \& Gardiner, H. (2001). Çocuk ve Ergen Gelişimi, Çev. Bekir Onur, Ankara: İmge Kitabevi Yayınları.

[13] Güneş, F. (2014). Türkçe öğretimi yaklaşımlar ve modeller. (2. Bask1). Ankara: Pegem A

[14] Hidi, S. \& Boscolo, P. (2006). Motivation and Writing (Chapter 10). Handbook of Writing. In Macarthur, C., Graham, S. And Fitzgerald, J., Research (Eds.). New York: The Guilford Press.

[15] Jacobs, J. E., \& Eccles, J. S. (1992). The impact of mothers' gender-role stereotypic beliefs on mothers' and children's ability perceptions. Journal of Personality and Social Psychology, 63(6), 932-944.

[16] Karasar, N. (2002). Bilimsel Araştırma Yöntemleri. Ankara: Nobel Yayınları

[17] Lam, S. F. \& Law, Y. K. (2007). The roles of instructional practices and motivation in writing performance. The Journal of Experimental Education, 75(2), 145-164.

[18] Large, C. M.; Maholovich, W. A.; Hopkins, L. J. Menig ; Rhein, D. M. \& Zwolinski, L. J. (1997). Improving and Motivating Children's Writing. Journal of Educational Research, 1-81. (Eric Document No: ED411 516) 
[19] Lo, J. \& Hyland, F. (2007). Enhancing students' engagement and motivation in writing: The case of primary students in Hong Kong. Journal of Second Language Writing, 16, 219237.

[20] Malecki, C. K. \& Jewell, J. (2003). Developmental, gender, and practical considerations in scoring curriculum-based measurement writing probes. Psychology in the Schools, 40, 379-390.

[21] Mata, L. (2011). Motivation for reading and writing in kindergarten children. Reading Psychology, 32, 272-299.

[22] Meece, J. \& Miller, S. (1999). Changes in elementary school children's achievement goals for reading and writing: Results of a longitudinal and intervention study. Scientific Studies of Reading, 3, 207-229.

[23] Meece, C., L., Glienke, B., B. ve Burg, S. (2006). Gender and Motivation. Journal of School Psychology, 44, 351-373.

[24] Meyers, L. S., Gamst, G. ve Guarino, A. J. (2006). Applied multivariate research. Design and interpretation. California: Sage Publication

[25] Onuk, Ö. (2007). Müzik Öğretmenliği Lisans Programı Öğrencilerinin Öğretmenliğe Güdülenmeleri ile Akademik Başarıları Arasındaki İlișki. Gazi Üniversitesi Eğitim Bilimleri Enstitüsü. Doktora Tezi

[26] Özkara, Y. (2007). 6+1 analitik yazma ve değerlendirme modelinin 5. sınıf öğrencilerinin hikâye edici metin yazma becerilerini geliştirmeye etkisi. Doktora Tezi. Gazi Üniversitesi, Eğitim Bilimleri Enstitüsü, Ankara.

[27] Özgeylani, F.H. (1993). Self-Concept and Body Image Of High School Male Athletes And Non-Athletes. Yayınlanmamış Yüksek Lisans Tezi, ODTÜ, Ankara.

[28] Pajares, F. \& Valiante, G. (1997). Influence of self-efficacy on elementary students' writing. The Journal of Educational Research, 90, 353-360.

[29] Pajers, F. ve Valantine G., (2001). Gender Differences in Writing Motivation and Achievement of Middle School Students: A Function of Gender Orientation. Contemporary Educational Psychology, 26, 366-381.

[30] Ruble, D. N.,\& Martin C. L. (1998). Gender development. In N. Eisenberg (Ed.), Handbook of child psychology: Vol 3. Social, emotional, and personality development (5th ed, pp. 993-1016). New York: Wiley.

[31] Ryan, R. M. \& Deci, E. L. (2000). Intrinsic and extrinsic motivation: Classic definitions and new directions. Contemporary Educational Psychology, 25, 54-67.

[32] Schumacker, R. E. \& Lomax, R. G. (2004). A beginner's guide to structural equation modeling. New Jersey: Lawrence Erlbaum Ass.

[33] Takımcıgil Özcan, S. (2014). İlkokul 4. sınıf öğrencilerinin yazma motivasyonları ile hikâye yazma becerilerinin değerlendirilmesi. Yüksek Lisans Tezi. Sakarya Üniversitesi Eğitim Bilimleri Enstitüsü, Sakarya.

[34] Temizkan, M. (2011). Yaratıcı yazma etkinliklerinin öykü yazma becerisi üzerindeki etkisi. Kuram ve Uygulamada Eğitim Bilimleri. 11 (2). 919-940.

[35] Tompkins, G. E. (2008). Teaching writing: Balancing process and product. Boston: Pearson

[36] Toy, Ö. (2007). Biyoloji Dersinde Kullanılan Öğrenme Stratejileri ve Başarı Güdüsü Arasındaki İlişkiler. Dokuz Eylül Üniversitesi Eğitim Bilimleri Enstitüsü. Yüksek Lisans Tezi.

[37] Troia, G., A., Harbaugh, A., G., Shankland R., K., Wolbers, K., A. \& Lawrence, A., M. (2012). Relationships between writing motivation, writing activity, and writing performance: effects of grade, sex, and ability. Reading and Writing, 26 (1), 17-44.

[38] Uzuner, S. (2007). Yenilenen program çerçevesinde birinci kademe Türkçe ders kitaplarında yer alan öyküleyici metinlerin sınıf öğretmenleri açısından algılanma yeterliliklerinin tespiti ve Türkçe öğretiminin amaçlarına uygunluğunun belirlenmesi. Yayınlanmamış Yüksek Lisans Tezi, Atatürk Üniversitesi, Sosyal Bilimler Enstitüsü, Türkçe Eğitimi Anabilim Dalı, Erzurum.

[39] Yıldız, M. (2013, Mayıs). Okuma motivasyonu profilinin Türkçe'ye uyarlanması: Geçerlik ve güvenirlik çalıșması, 12. Sınıf Öğretmenliği Sempozyumu, Adnan Menderes Üniversitesi, Aydın.

[40] Yıldız, M., Aktaş, N., Yekeler, A. D. \& Ataş, M. (2016). İlköğretimde (1-8. Sinıf) hikâye yazma becerisinin gelişimi.15. Uluslararası Sınıf Öğretmenliği Sempozyumu'nda sunulan bildiri, Muğla.

[41] Y1lmaz, E. (2007). Ortaöğretimde İngilizce Derslerinde Öğrenci Başarısında Motivasyonun Rolü: Bartın İli Örneği. Zonguldak Karaelmas Üniversitesi Sosyal Bilimler Enstitüsü. Yüksek Lisans Tezi.

[42] Wang, C. K. J. \& Liu W. C. (2008). Teacher's motivation to teach national education in Singapore: A self-determination theory approach. Asia Pacific Journal of Education, 28 (4), $395-410$.

[43] Wood, D., Kaplan, R., \& McLoyd, V. C. (2007). Gender differences in the educational expectations of urban, low-income African American youth: The role of parents and the school. Journal of Youth Adolescence, 36, 417-427. 